
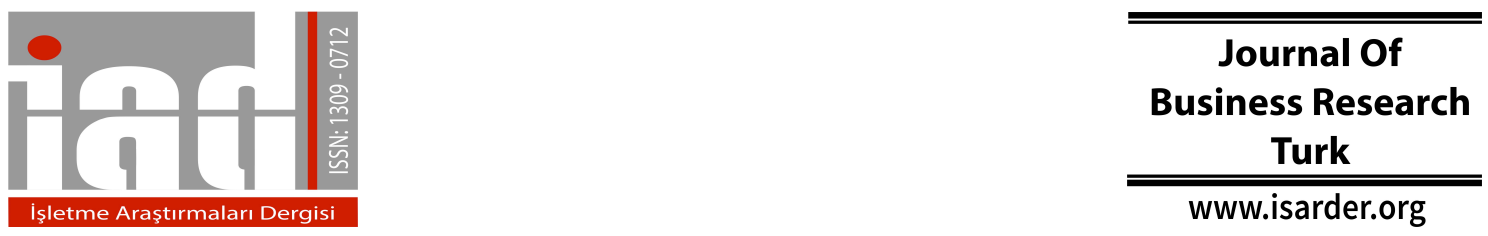

\title{
The Impact of Social Media Pages on Customer Equity and Purchase Intention; An Empirical Study of Mobile Operators
}

\author{
Alkan ALKAYA \\ Uşak University \\ School of Health \\ Uşak, Turkey \\ orcid.org/0000-0002-9917-200X \\ alkan.alkaya@usak.edu.tr
}

\author{
Ercan TAŞKIN \\ Dumlupınar University \\ Faculty of Economics and Administrative \\ Science, Kütahya, Turkey \\ orcid.org/0000-0001-8499-1013 \\ ercan.taskin@dpu.edu.tr
}

\begin{abstract}
The competitive conditions of the market, the desire to reach the target group directly, and the increasing interest of the consumers to the social media today make the use of social media inevitable. This study set out to identify attributes of marketing communication activities via social media pages of mobile operators in Turkey and examine the relationships among customer equity components (value equity, relationship equity, brand equity) and purchase intention through a structural equation modelling. According to results of the study marketing communication via social media pages has been found to be effective in all components of the customer equity, but value equity does not have a significant effect on purchase intention and there was no relationship between marketing communication via social media pages and purchase intention. The findings of this study can provide an overview of the relationship between social media and customer equity and enable mobile operators to forecast the future purchase intention of their customers more accurately, and it may also provide a guide to managing marketing activities especially on social media as well.
\end{abstract}

Keywords: social media, purchase intention, customer equity, value equity, relationship equity, brand equity

\section{Introduction}

With the development of information technology and the increase of the market in this area, the growing customer volume has increased the importance of mobile operators in the market. Mobile industry is one of the value-added industry and it plays important role both in promoting their own brand and in promoting other brands. The increasing tendency to mobile phones especially on smartphones creates many advantages for mobile operators in communicating with their customers. Developments in mobile technology and mobile infrastructure, and interest in social media platforms in recent years, have made social media a new means of engagement in reaching out to customers. As alternative methods, such as creating social media pages in marketing communication, has emerged and has become popular, ways of reaching potential customers are increasing. 
The way to build customer assets is to communicate effectively with customers. Social media platforms offer two-way communication advantage thanks to web 2.0 technology that allows customers to use the tools whatever they want, wherever they want, and whenever they want, without the constraints of traditional one-way communication. Thus, for a presence in social media, the mobile operator like most companies are communicating with page turning customers on these platforms. There are many online social media platforms such as blogs or social networking that businesses can use. Mobile operators can choose a social media for example Facebook, Twitter or YouTube of which they consider important, and can open a page there or create their own blog pages. This can enable companies to have strong relationships with customers.

Strong relationships are crucial to companies' long-term customer equity. Increasing use of social media by mobile operators, like other companies, is increasing the need to identify and quantitatively analyze the impact of social media. Thus, the purpose of this study is to define the structure of the social media pages of mobile operators and to determine their impact on customer equity and the purchase intention.

The aim of this study is to create a road map for managing and evaluating the performance of companies. It will also enable companies to set out a strategy to improve their business performance by identifying specific factors related to the customer equity and purchase intention. In addition, it is aimed to provide opinions to other companies in the estimation of the purchasing behavior of the customers after the findings obtained from the mobile operators.

\section{Social media pages}

There is no single generally accepted definition of the concept of social media. However, Quan-Haase and Young (2010) consider social media as just a moving target, and suggests that it is impossible to find generally accepted definition of it. Other than that, there are many definitions of social media in the literature. Considering the definitions, social media is; which are aimed at making interaction; applications created by users and enriched by internet users (Cornelius, Komito, \& Bates, 2009) web-based applications that allow the creation and development of ideological and technological content on web 2.0, user-centric structures (Kaplan \& Haenlein, 2010). and online places where people with common interests share their thoughts, interpretations and ideas (Weber, 2009).

Businesses communicate with consumers through social media pages. There are many opinions on the classification of social media as it is in the definition. Basically, the social media classification on which it is agreed is online social networks, publishing, photography, audio, video, microblogging, live cast, virtual worlds, games, creative applications, aggregators, RSS, search, interpersonal and mobile. (Blossom, 2011; Kaplan \& Haenlein, 2010; Mangold \& Faulds, 2009; Mayfield, 2007; Safko \& Brake, 2009; Worldwide, 2008).

Shi, Rui, and Whinston (2013) explain the differences in classifications on social media over time with the blurring of sharpness between the classes. For example, they state that Twitter is a combination of broadcasting service and social networking, so it can also be classified as 'social broadcasting technology'. 


\section{A. Alkaya - E. Taşkın 9/3 (2017) 122-133}

Social media is an effective marketing tool. It also fulfills many functions. Through the social media pages, communication and relationships between people are increased and a very big environment is created online (Pempek, Yermolayeva, \& Calvert, 2009). In this way, businesses can reach their target groups. Social media has an important role to play on customers and potential customers. Using social media platforms, consumers can easily share positive and negative criticisms about the products they buy and how to use the product. With this advantage, potential customers have detailed information about the product before making a purchase and use it to decide (Jerving, 2009).

\section{Customer equity}

In the context of a relationship-based marketing approach, the concept of customer equity, which is considered as the sum of customer's lifetime values, is a concept in which the customers are considered as an asset and both quantitative and qualitative values are determined (Altıntaş, 2006). The concept of customer equity first emerged by working with Blattberg and Deighton (1996) and Dorsch and Carlson (1996). In the literature, customer equity is described as discounted sum of life-time value of existing and potential customers of an organization. (Blattberg \& Deighton, 1996; Dorsch \& Carlson, 1996; Hogan, Lemon, \& Rust, 2002; Kumar \& George, 2007; Persson \& Ryals, 2010; Rust, Lemon, \& Zeithaml, 2004). The basis of the customer equity is the customer's lifetime value (Drèze \& Bonfrer, 2008).

There are several approaches in the literature to address the concept of consumer equity. While some studies focus on models of customer lifetime value and the calculation of customer equity (Berger \& Nasr, 1998; Jain \& Singh, 2002), another work area has also focused on introducing the concept components (Bruhn, Schoenmueller, \& Schäfer, 2012; Zeithaml, Lemon, \& Rust, 2001). Many studies reveal that customer equity consists of three factors: value equity, brand equity and relationship equity (Lemon, Rust, \& Zeithaml, 2001; Leone et al., 2006) These three factors work independently or together. By developing these three factors, companies can develop their total customer equity (Hyun, 2009).

Value equity consists of the value perceived by the customers regarding the products of the businesses. In other words, value equity can be expressed as an evaluation of the benefits that a customer earns from a product and the concessions given by a customer (Zeithaml et al., 2001). Brand equity consists of all of the values added on products reinforced with brand name and brand symbol. In other words, the intangible value of the product, which cannot be measured by the current price or other quantitative means, is called brand equity (Aaker, 1992). Brand equity can be expressed as a difference in consumer perceptions and behaviors when compared to a branded product, a similar product without a brand. The basis of brand development efforts is to create a brand-specific equity. The equity expressed here is a concept that increases the market value of an business or a brand and is created by the business as a brand value of the consumer and ultimately represents a financial value for the business (Tek \& Özgül, 2010). The concept of relationship equity is defined as the equity of the relationships established with interest groups outside the business, such as customers, sources of supply, lobbies and public institute (Ercan, Öztürk, \& Demirgüneş, 2003). Relationship Equity is the tendency of the customer to stick with the brand, above and beyond the customer's objective and subjective assessments of the brand, based on corporate efforts 
to build and reinforce the relationship (Aravindakshan, Rust, Lemon, \& Zeithaml, 2004). According to Wilson, Zeithaml, Bitner, and Gremler (2017) an increase in customers' purchasing behavior, a reduction in costs at a certain rate, and thus an increase in the life-long value of the customers indicates that an business has adopted a relationship marketing. Businesses have a variety of components to increase their relationship equity. These can be counted as loyalty programs, special recognition and treatment, affinity/interest programs, community and information creation programs (Zeithaml et al., 2001).

\section{Purchase intention}

Isaksson and Xavier (2009) state that the most important concept that has a decisive role in the decision-making phase of procurement is purchase intention. This concept is defined as a concept that expresses the possibility of purchasing a product by a shopper. Purchase intention is the tendency to purchase a particular product or service that is affected by customers' perceptions, attitudes and satisfaction (Morrison, 1979; Spreng, MacKenzie, \& Olshavsky, 1996; Taylor \& Baker, 1994). However, this concept also implies the possibility of proposing the purchase and the product or service to others (Dodds, Monroe, \& Grewal, 1991; Prendergast, Ko, \& Siu Yin, 2010).

Previous research shows that attitudes and preferences towards products or brands have very close ties to each other. Therefore, measurement of purchase intention aims to reveal future behavior of consumer based on their attitudes. Purchase intention is an attitudinal variable for measuring the future contribution of customers to the brand, whereas the customer equity is a behavioral variable that really results in sales. Predicting customers' future behavior is crucial for clearly calculating the company's future behavior (Kim \& Ko, 2012). The prediction of the future behavior of the consumer, especially the purchasing behavior, is the most important dimension of planning. The perception of consumers' purchase intentions is seen as an important factor for companies seeking consumers, seeking to retain consumers and pursue their lives in a competitive environment.

\section{Design of hypotheses}

The main objective of businesses is to increase long-term profitability. Therefore, the marketing activities of the businesses interacting with the customers through the social media pages are also carried out in order to develop the relationship and increase the sales and profitability. According to Srivastava, Shervani, and Fahey (1998) marketing is an investment that enhances customer equity drivers. Therefore, it is anticipated that the hypotheses developed below will have a positive effect on the customer equity drivers of the marketing communications of businesses via social media pages.

$\mathbf{H}_{1}$. Marketing communications via social media pages have a positive effect on value equity.

H2. Marketing communications via social media pages have a positive effect on brand equity.

$\mathbf{H}_{3}$. Marketing communications via social media pages have a positive effect on the relationship equity.

Attitudes are important for determining future behavior, because attitudes lie at the root of behaviors. Therefore, it is likely that the customer equity components have 
similar effects on the purchase intention. In addition, it can be said that marketing communication via social media pages has a significant effect on the purchase intention. In this context, the following hypotheses have been established.

$\mathbf{H}_{4}$. Value equity relates positively to purchase intention.

$\mathbf{H}_{5}$. Brand equity relates positively to purchase intention.

$\mathbf{H}_{6}$. Relationship equity relates positively to purchase intention.

H7. Marketing communications via social media pages relates positively to purchase intention.

\section{Method}

\subsection{Preliminary test}

Before the questionnaires were finalized, 30 students were pre-tested in order to determine the reliability of the questionnaires to be understood by the responders. Cronbach's alpha and item total correlation for each implicit variable were at an acceptable level (George \& Mallery, 2003).

\subsection{Measures}

While the questionnaires were prepared, literature studies were made. The questions were taken from the scales used in previous studies. Eleven items for measuring marketing communications via social media pages were gathered from Kim and Ko (2012). Six items for measuring value equity were developed in accordance with Zeithaml et al. (2001) and Chow (2013). Nine items for measuring brand equity were developed in accordance with Pappu, Quester, and Cooksey (2005); Vogel, Evanschitzky, and Ramaseshan (2008); (Yasin \& Zahari, 2011). Eight items for measuring relationship equity were developed in accordance with Bruhn et al. (2012); Chow (2013); Hennig-Thurau, Gwinner, and Gremler (2002); Zeithaml et al. (2001). Four items for measuring purchase intention were developed in accordance with Bruhn et al. (2012); Dodds et al. (1991); Vogel et al. (2008).

\subsection{Sample and data collection}

Considering the research area, the numbers of three mobile operators in social media such as members, followers and fans are taken into account. Students of Uşak University were selected as population. Students who are familiar with the social media activities of mobile operators, members of social media pages, followers or fans have participated in the research. Social media pages of mobile operators have been consciously selected as application examples. The reasons are; the first is that one of the sectors that is actively in social media in Turkey is mobile operators. The second is that this area has a significant number of members, followers or fans. Thirdly, according to the report of Information and Technology Institute in Turkey, all operator have a total of 72 million subscribers (BTK, 2016). The main reason for choosing the main statistical population and sample as university students is that the students use mobile operators and social media actively, it is easy to get obtain data, and students can be evaluated as a potential customer. According to Blattberg, Getz, and Thomas (2001) potential customers are increasing customer equity. Data were collected by means of a questionnaire from April 3 to 30, 2016. 700 questionnaires were distributed and, 663 were finally analyzed after excluding incomplete responses. 


\subsection{Data analysis}

In order to achieve the purpose of this study and to test hypotheses, the SPSS and AMOS statistics package programs were used. With SPSS, descriptive analysis was adopted to analyze the results of the preliminary test and to find out demographic characteristics of the sample. Cronbach's alfa was adopted to test reliability. Using AMOS, confirmatory factor analysis was conducted to prove the validity of each instrument, while structural equation modeling was used to test hypotheses.

\section{Findings}

\subsection{Demographic analysis}

According to the gender distribution of the participants, $62.6 \%$ of the participants are female. In terms of education, $17.6 \%$ of the participants have associate degree, $79.5 \%$ have undergraduates and $2.9 \%$ have graduate degree. According to these results, number of the participants at the undergraduate level in terms of education level is significantly higher. Some of the university students can also work in a job when they are studying for various reasons. $10.3 \%$ of the participants stated that they were working while they were studying. Considering the income situation, most students stated that they have with an income level of 500 TRY or less per month which constitutes $63 \%$ of the participants. $27.1 \%$ of students have $551-1000$ TRY, 5.6\% of them have 1001-1501 TRY and $4.2 \%$ of them have 1501 TRY and above income levels.

In terms of operator preference, $49.2 \%$ of the participants use Turk Telekom, $31.7 \%$ use Vodafone and $19.1 \%$ use Turkcell. This result also shows that all of the respondents are telephone owners. When asked how long they have been involved in social media, 59\% of participants said they have been in social media for more than 4 years. $18.1 \%$ of participants $3-4$ years, $13.9 \%$ participants $1-2$ years and $8.7 \%$ participants less than 1 year. Therefore, it appears that a large proportion of participants have used social media for many years.

For the question of how much time they spend in social media during the day, $46.5 \%$ of the participants stated that they spend $2-4$ hours in social media. $34.2 \%$ said they spend less than 1 hour, $11.3 \%$ spend $4-6$ hours and finally $8 \%$ spend more than 6 hours on social media. These results show that participants spend a significant amount of their time on social media.

In the open-ended question asked about what social media is the most followed up, it was found that $76.3 \%$ of the respondents were using Facebook, 10.7\% were using Twitter, 10.1\% were using Instagram, and 2.9\% were using YouTube. This result shows that Facebook is the most popular social media platform among students.

Participants were asked about the tools they used to use social media, $82.2 \%$ said they used mobile phones and $17.8 \%$ used computers and similar devices. In addition, there is also a conclusion that university students have a significantly higher use of social media on their mobile phones.

\subsection{Measurement model}

Kaiser-Meyer-Olkin (KMO) Test for Sampling Adequacy and Bartlett's Test of Sphericity were applied to test whether the data were appropriate for factor analysis. Since the test significance level is lowered from .05 this value indicates that the correlation matrix is not a unit matrix and the existence of relations between variables. It can also be said that the data set is suitable for factor analysis. 
Table 1. Kaiser-Meyer-Olkin (KMO) Test for Sampling Adequacy and Bartlett's Test of Sphericity

\begin{tabular}{|l|l|l|}
\hline & Factor Analysis & Acceptance Level \\
\hline KMO Test & .899 & $.60<$ \\
\hline Bartlett's Test of Sphericity & .000 (Sig.) & $<.05$ (Sig.) \\
\hline
\end{tabular}

The scales used in the research were subjected to exploratory factor analysis and the factor ranges of the items and Cronbach's alpha values of each factor were determined.

Table 2. Results of Exploratory Factor Analysis

\begin{tabular}{|l|l|l|l|}
\hline & Factor Loading & Item & Cronbach's Alfa \\
\hline Social media pages & $.44-.85$ & 11 & .80 \\
\hline Value equity & $.51-.72$ & 6 & .75 \\
\hline Brand equity & $.49-.75$ & 9 & .80 \\
\hline Relationship equity & $.46-.70$ & 8 & .80 \\
\hline Purchase intention & $.51-.89$ & 4 & .84 \\
\hline
\end{tabular}

In order to show the validity of the scales used in the research and to show how well the observed variables explained the theoretical implicit variables, confirmatory factor analysis with a single factor was applied to the five theoretical implicit variables shown in the conceptual model (Hair, Anderson, Babin, \& Black, 2010). According to the regulations, the modification indices reached acceptable levels and the validity of the scales was achieved when three items of social media pages, one item of value equity, three items of brand equity and three items of relationship equity were extracted.

\subsection{Structural model}

In order to develop the model in the research, the findings in the literature study were transformed into hypotheses and models were formed within these hypotheses. Structural equation modeling method was used to test the model; path analysis was used for the analysis of the causal relations of the model put forward theoretically. Fig. 1 shows the findings.

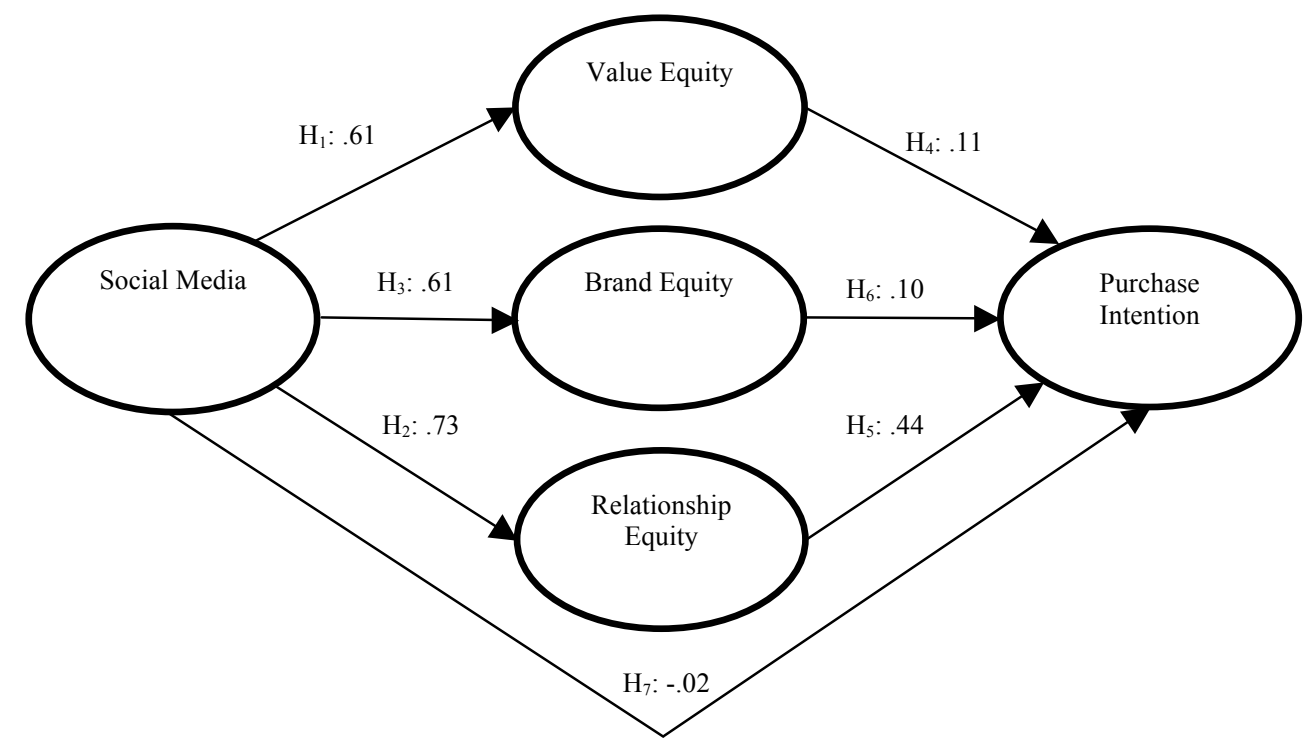

Modification indices: $\mathrm{X}^{2} / \mathrm{df}=2.5, * * * \mathrm{p}<=.000$

$\mathrm{AGFI}=.90, \mathrm{NFI}=.86, \mathrm{CFI}=.91, \mathrm{RMR}=.07, \mathrm{RMSEA}=.05$

Figure 1. Results of structural equation model 
The t-values in the confirmatory factor analysis and the level of correlation between the result of examining the modification indices and the errors of some items are taken into consideration and revised accordingly. For this purpose, below the critical value of 't-value', the components with high level of relation with each other and the items with less harmony with the model in this direction were extracted. The model was once again subjected to the measurement to try to reach the ideal result.

The satisfactory result of model fitting suggests that predicted structural coefficients can be evaluated in terms of testing hypotheses. The standardized regression coefficient values of the model-related hypotheses measured in the study are shown in Table 3.

Table 3. Results of the research model

\begin{tabular}{|l|l|l|}
\hline & C.R.* & P** \\
\hline H1: Social media $\rightarrow$ Value equity & 6.419 & $* * *$ \\
\hline H2: Social media $\rightarrow$ Brand equity & 6.387 & $* * *$ \\
\hline H3: Social media $\rightarrow$ Relationship equity & 6.570 & $* * *$ \\
\hline H4: Social media $\rightarrow$ Purchase Intention & .191 & .848 \\
\hline H5: Brand equity $\rightarrow$ Purchase Intention & 3.713 & $* * *$ \\
\hline H6: Value equity $\rightarrow$ Purchase Intention & 1.145 & .252 \\
\hline H7: Relationship equity $\rightarrow$ Purchase Intention & 4.422 & $* * *$ \\
\hline
\end{tabular}

*Critical Ratio, $* *$ p $<.01$

Each way of marketing communication via social media pages on value equity, brand equity and relationship equity was significant at $p=.000$ level; social media pages were found to have a positive and strong impact on value equity $(\beta=.618)$, brand equity $(\beta=.575)$ and relationship equity $(\beta=.737)$. Therefore, marketing communication via social media pages has a positive effect on increasing customer equity. Each way on purchase intention of the brand equity and relationship equity was significant at $p=.000$ level. It has been determined that brand equity has a weak but significant effect on purchase intention $(\beta=.244)$ and similarly, it has been determined that relationship equity has a weak but significant effect on purchasing intention $(\beta=.354)$. There was no significant effect both of the marketing communication via social media pages $(p=.848)$ and value equity $(\mathrm{p}=.252)$ on purchase intention.

\section{Conclusions and implications}

This study investigates the effect of marketing communications on the customer equity components and purchase intention of mobile operators via social media pages. The findings of the study show that creating social media pages is effective in increasing future profitability for mobile operators. The results obtained are as follows.

Firstly, according to the study results, marketing communication via social media pages has been found to be effective in all components of the customer equity, because marketing communication via social media pages has been verified and found effective at each component. The basis of marketing communication is to increase customer relationships, to improve customer equity and to create an intention to buy. Social media also contributes in this sense as a new means of marketing communication. Particularly, according to the results of the research, the students who stated that they mostly enter social media via mobile phones also make it important for mobile operators to use social media effectively. This result, which is gained according to the 
importance of social media, can evaluate other businesses to make a positive contribution to their brands.

Secondly, it has been found that value equity does not have a significant effect on purchase intention, although there is a significant impact on purchase intention separately from brand equity and relationship equity. It can be said that the quality expectations of the customers are not met by mobile operators as competently as the reasons for this. In addition, it can be said that the prices determined by the services are also high or rightfully earned by the customers. Indeed, it is possible to imagine that the price is higher for the service provided when compared to other countries. Finally, it can also be said that customers feel a lack of how much of the service offered meets customer expectations, or how much of the service meets a customer's needs.

Thirdly, there was no significant impact marketing communications via social media pages on purchase intention. Indeed, social media activity without traditional marketing activities does not see a corresponding response to customers' purchase intention.

\section{Limitations and future research}

The results show that the presence of businesses in social media and their active presence are important for their future. The research was conducted via mobile operators as a service business. Mobile operators do not have a wide variety of social media pages. In other words, these businesses communicate via 3-4 social media pages. Instead, new research can be done in sectors that produce both product and service using different social media platforms for specific target groups.

Future work may develop more powerful tools to gauge the impact of marketing communications via social media. Furthermore, this research is also a research in the field of B2C and it can be suggested to make it in the B2B field which is thought to be able to offer differences. In particular, the content that will be used on social media pages in this area will vary. Beside this, target groups and their measurement will also diversify the viewpoint of the subject as a separate research topic.

The research was conducted on students using social media. However, social media has many different consumer groups in terms of age groups, occupational groups or income levels. Social media pages, for example, do not intend to buy meaningfully on students, whereas this research is likely to produce meaningful results on another target groups.

In conclusion, this study is thought an important source of guidance for businesses that want to take part in the social media platform. Furthermore, it is thought that it will provide significant contributions to the literature if it is examined in various dimensions such as measurements and types of social media, and B2B. 


\section{References}

Aaker, D. A. (1992). The value of brand equity. Journal of business strategy, 13(4), 2732.

Altıntaş, M. H. (2006). Müşteri sermayesi yönetimi. Ístanbul: Aktüel Publishing.

Aravindakshan, A., Rust, R. T., Lemon, K. N., \& Zeithaml, V. A. (2004). Customer equity: Making marketing strategy financially accountable. Journal of systems science and systems engineering, 13(4), 405-422.

Berger, P. D., \& Nasr, N. I. (1998). Customer lifetime value: Marketing models and applications. Journal of Interactive Marketing, 12(1), 17-30.

Blattberg, R. C., \& Deighton, J. (1996). Manage marketing by the customer equity test. Harvard business review, 74(4), 136-\&.

Blattberg, R. C., Getz, G., \& Thomas, J. S. (2001). Customer equity: Building and managing relationships as valuable assets: Harvard Business Press.

Blossom, J. (2011). Content nation: Surviving and thriving as social media changes our work, our lives, and our future: John Wiley \& Sons.

Bruhn, M., Schoenmueller, V., \& Schäfer, D. B. (2012). Are social media replacing traditional media in terms of brand equity creation? Management Research Review, 35(9), 770-790. doi:doi:10.1108/01409171211255948

BTK (2016). 2015 Faaliyet Raporu. Retrieved from https://www.btk.gov.tr/File/?path=ROOT\%2f1\%2fDocuments\%2fSayfalar\%2fF aaliyet_Raporlari\%2f2015_Faaliyet_Raporu.pdf

Chow, B. (2013). The comparison of social and traditional media marketing impacts on customer equity and purchase intention in luxury fashion business. (Bachelor of Arts), The Hong Kong Polytechnic University.

Cornelius, I., Komito, L., \& Bates, J. (2009). Virtually local: social media and community among Polish nationals in Dublin. Paper presented at the Aslib Proceedings.

Dodds, W. B., Monroe, K. B., \& Grewal, D. (1991). Effects of price, brand, and store information on buyers' product evaluations. Journal of marketing research, 307319.

Dorsch, M. J., \& Carlson, L. (1996). A transaction approach to understanding and managing customer equity. Journal of Business Research, 35(3), 253-264.

Drèze, X., \& Bonfrer, A. (2008). An empirical investigation of the impact of communication timing on customer equity. Journal of Interactive Marketing, 22(1), 36-50.

Ercan, M. K., Öztürk, M. B., \& Demirgüneş, K. (2003). Değere Dayalı Yönetim ve Entelekütel Sermaye: Gazi Kitabevi.

George, D., \& Mallery, M. (2003). Using SPSS for Windows step by step: a simple guide and reference.

Hair, J. F., Anderson, R. E., Babin, B. J., \& Black, W. C. (2010). Multivariate data analysis: A global perspective (Vol. 7): Pearson Upper Saddle River, NJ.

Hennig-Thurau, T., Gwinner, K. P., \& Gremler, D. D. (2002). Understanding relationship marketing outcomes an integration of relational benefits and relationship quality. Journal of service Research, 4(3), 230-247.

Hogan, J. E., Lemon, K. N., \& Rust, R. T. (2002). Customer equity management: Charting new directions for the future of marketing. Journal of service Research, 5(1), 4-12. 
Hyun, S. S. (2009). Creating a model of customer equity for chain restaurant brand formation. International Journal of Hospitality Management, 28(4), 529-539.

Isaksson, J., \& Xavier, S. (2009). Online communities-segments and buying behaviour profiles.

Jain, D., \& Singh, S. S. (2002). Customer lifetime value research in marketing: A review and future directions. Journal of Interactive Marketing, 16(2), 34-46.

Jerving, J. (2009). Networking as a Marketing Tool. Marketing\&Business Development, January, 1-25.

Kaplan, A. M., \& Haenlein, M. (2010). Users of the world, unite! The challenges and opportunities of Social Media. Business Horizons, 53(1), 59-68. doi:http://dx.doi.org/10.1016/j.bushor.2009.09.003

Kim, A. J., \& Ko, E. (2012). Do social media marketing activities enhance customer equity? An empirical study of luxury fashion brand. Journal of Business Research, 65(10), 1480-1486.

Kumar, V., \& George, M. (2007). Measuring and maximizing customer equity: a critical analysis. Journal of the Academy of Marketing Science, 35(2), 157-171.

Lemon, K. N., Rust, R. T., \& Zeithaml, V. A. (2001). What drives customer equity. Marketing management, 10(1), 20.

Leone, R. P., Rao, V. R., Keller, K. L., Luo, A. M., McAlister, L., \& Srivastava, R. (2006). Linking brand equity to customer equity. Journal of service Research, 9(2), 125-138.

Mangold, W. G., \& Faulds, D. J. (2009). Social media: The new hybrid element of the promotion mix. Business Horizons, 52(4), 357-365.

Mayfield, A. (2007). What is Social Media [M/OL].

Morrison, D. G. (1979). Purchase intentions and purchase behavior. The Journal of Marketing, 65-74.

Pappu, R., Quester, P. G., \& Cooksey, R. W. (2005). Consumer-based brand equity: improving the measurement-empirical evidence. Journal of Product \& Brand Management, 14(3), 143-154.

Pempek, T. A., Yermolayeva, Y. A., \& Calvert, S. L. (2009). College students' social networking experiences on Facebook. Journal of applied developmental psychology, 30(3), 227-238.

Persson, A., \& Ryals, L. (2010). Customer assets and customer equity: Management and measurement issues. Marketing Theory, 10(4), 417-436.

Prendergast, G., Ko, D., \& Siu Yin, V. Y. (2010). Online word of mouth and consumer purchase intentions. International Journal of Advertising, 29(5), 687-708.

Quan-Haase, A., \& Young, A. L. (2010). Uses and gratifications of social media: A comparison of Facebook and instant messaging. Bulletin of Science, Technology \& Society, 30(5), 350-361.

Rust, R. T., Lemon, K. N., \& Zeithaml, V. A. (2004). Return on marketing: Using customer equity to focus marketing strategy. Journal of marketing, 68(1), 109127.

Safko, L., \& Brake, D. K. (2009). The Social Media Bible: Tactics. Tools \& for Business Success, Hoboken, New Jersey.

Shi, Z., Rui, H., \& Whinston, A. B. (2013). Content sharing in a social broadcasting environment: evidence from twitter.

Spreng, R. A., MacKenzie, S. B., \& Olshavsky, R. W. (1996). A reexamination of the determinants of consumer satisfaction. The Journal of Marketing, 15-32. 
Srivastava, R. K., Shervani, T. A., \& Fahey, L. (1998). Market-based assets and shareholder value: A framework for analysis. The Journal of Marketing, 2-18.

Taylor, S. A., \& Baker, T. L. (1994). An assessment of the relationship between service quality and customer satisfaction in the formation of consumers' purchase intentions. Journal of retailing, 70(2), 163-178.

Tek, Ö. B., \& Özgül, E. (2010). Modern Pazarlama Illkeleri: Uygulamalı Yönetimsel Yaklaşım. İzmir.

Vogel, V., Evanschitzky, H., \& Ramaseshan, B. (2008). Customer equity drivers and future sales. Journal of marketing, 72(6), 98-108.

Weber, L. (2009). Marketing to the social web: How digital customer communities build your business: John Wiley \& Sons.

Wilson, A., Zeithaml, V. A., Bitner, M. J., \& Gremler, D. D. (2017). Services marketing: Integrating customer focus across the firm: McGraw Hill.

Worldwide, D. (2008). Engaging consumers online: the impact of social media on purchasing behavior. Volume one: Initial findings, United States.

Yasin, N., \& Zahari, A. (2011). Does family and viral marketing have any effect on brand equity? Contemporary Marketing Review, 1(8), 1-13.

Zeithaml, V. A., Lemon, K. N., \& Rust, R. T. (2001). Driving customer equity: How customer lifetime value is reshaping corporate strategy: Simon and Schuster. 